\title{
Pancreatic endoproteases and pancreatic secretory trypsin inhibitor immunoreactivity in human Paneth cells
}

\author{
M BOHE, $¥$ A BORGSTRÖM, ${ }^{*}$ C LINDSTRÖM,† K OHLSSON $\ddagger$ \\ From the *Departments of Surgery, $\uparrow$ Pathology, and $\ddagger$ Surgical Pathophysiology, University of Lund, Malmö \\ General Hospital, Malmö, Sweden
}

SUMMARY Normal and metaplastic gastrointestinal mucosa obtained at surgical resection were studied by light microscopy, using the unlabelled antibody enzyme method for immuno: histochemical staining of lysozyme, pancreatic endoproteases, and pancreatic secretory trypsin? inhibitor (PSTI). Paneth cells in the mucosa of normal small intestine, gastric mucosa with intestina metaplasia, and colonic metaplastic mucosa were found to contain anionic trypsin, cationic trypsin $\frac{\bar{x}}{\bar{x}}$ lysozyme, and PSTI immunoreactivity, but not chymotrypsin and elastase immunoreactivity $\vec{\bullet}$ Normal gastric and colonic mucosa and some goblet cells in the small intestine showed positive PSTI immunoreactivity but no endoprotease immunoreactivity. The presence of immunoreactive trypsin and immunoreactive PSTI in the Paneth cells, which are of secretory type, probably indio s cates an important extrapancreatic source of these proteins rather than a storage of endocytosect material.

The Paneth cells originally described by Schwalbe in $1872^{1}$ and later by Paneth in $1888^{2}$ are normally found at the base of the crypts of Lieberkühn in the duodenum, jejunum, and ileum. Paneth cells are also found in metaplastic areas in gastric or colonic mucosa. ${ }^{3}$ They are ultrastructurally similar to secretory cells and like the pancreatic acinar cells, with apically located large cytoplasmatic granules. Among proposed properties and functions are the abilities to secrete immunoglobulins and lysozyme into the gut lumen and to eliminate metals from the mucosa into the luminal contents. ${ }^{4}$

Using an immunohistochemical technique, we found a trypsin like immunoreactivity in the Paneth cells in the duodenum, the small intestine, and in metaplastic areas in the gastric mucosa in man. ${ }^{5}$ The purpose of this investigation was to further characterise the trypsin like immunoreactivity and to determine if the Paneth cells also contain other pancreatic endoproteases as well as the pancreatic secretory trypsin inhibitor (PSTI).

Accepted for publication 7 January 1985

\section{Material and methods}

TISSUE SAMPLES

The material comprised different resection specimens taken during operation from various types of surgica cases. The specimens were fixed in $10 \%$ buffered fo malin and were imbedded in paraffin. The following types of mucosa were represented: normal mucosa from stomach, duodenum, jejunum, ileum, and colon, colonic mucosa from cases with ulcerative colitis containing glands with Paneth cell metaplasia; gastrix. mucosa of intestinal metaplastic type; and, in add] tion, colonic adenoma with Paneth cell metaplasia.

SPECIFIC MATERIAL

DEAE-Sephadex, Sepharose 4B, and prepacked PR 10 columns were obtained from Pharmacia Fife Chemicals, Uppsala, Sweden. Trasylol was providega by Bayer AG, West Germany. Swine antirabbit IgG, peroxidase and antiperoxidase (PAP), and norma swine serum were obtained from Daco Immơ noglobulins, Copenhagen, Denmark. Di-iso-propy fluorophosphate (DFP) was obtained from Sigma Chemicals (St Louis, United States of America). 
Pancreatic juice was obtained from patients who had had the main pancreatic duct drained after pancreatic surgery. The pancreatic juice was collected in tubes on ice and frozen within two hours at $-20^{\circ} \mathrm{C}$. Human cationic trypsin and human PSTI were purified at the laboratory. ${ }^{67}$

\section{ANTISERA}

Rabbit antisera against cationic trypsin, chymotrypsin, elastase 2, and PSTI were produced at the laboratory. ${ }^{58}$ Specific rabbit antihuman lysozyme serum was obtained from Professor Carl-Bertil Laurell, Malmö, Sweden.

\section{AFFINITY PURIFICATION OF ANIONIC TRYPSIN ON SEPHAROSE CONJUGATED TRASYLOL}

Trasylol $(150 \mathrm{mg}$ ) was coupled to $15 \mathrm{~g}$ cyanogen bromide activated Sepharose 4B, according to the manufacturer's instructions. Pancreatic juice $(50 \mathrm{ml})$ from a patient with a high concentration of anionic trypsinogen and only a small concentration of cationic trypsinogen was applied to the sepharose linked trasylol column $(2.5 \times 10 \mathrm{~cm})$, equilibrated with Tris hydrochloric acid buffer $0.01 \mathrm{M}$, containing $0.1 \mathrm{M}$ sodium chloride at $\mathrm{pH} 8$. After thorough washing with the starting buffer, until absorbance at $280 \mathrm{~nm}$ reached zero, the anionic trypsinogen was eluted with $0.01 \mathrm{M}$ formic acid containing $0.2 \mathrm{M}$ sodium chloride at $\mathrm{pH} 3 \cdot 0$. The fractions containing trypsinogen were desalted immediately on PD-10 columns, equilibrated with $0.001 \mathrm{M}$ hydrochloric acid, and lyophilised. The purified anionic trypsinogen showed only one protein band on agarose gel electrophoresis at $\mathrm{pH} 8 \cdot 6$ : after autoactivation this band has a slightly less anionic mobility. The anionic trypsin was inactivated with DFP by adding $10 \mu 1 \mathrm{DFP}(1 \mathrm{M} / \mathrm{l})$ in iso-propranol to $1 \mathrm{ml}$ of anionic trypsin $(1 \mathrm{mg} / \mathrm{ml})$ in hydrochloric acid $0.001 \mathrm{M} / 1$. After the addition of DFP the $\mathrm{pH}$ was adjusted to 7.0 by adding $100 \mu \mathrm{l}$ Tris buffer, $1 \mathrm{M} / \mathrm{l}$.

Antiserum against human anionic trypsin(ogen) was produced by immunising rabbits with human anionic trypsin inactivated with DFP and emulsified with Freund's adjuvant. Immunoelectrophoresis against human pancreatic juice before and after activation showed one strong anionic precipitate, corresponding to anionic trypsinogen and trypsin. Sometimes a faint precipitate was seen, corresponding to cationic trypsin(ogen), probably indicating a cross reaction between the two trypsins, as has been reported previously. ${ }^{9}$

IMMUNOADSORPTION OF RABBIT ANTISERA

AGAINST HUMAN ANIONIC AND CATIONIC

TRYPSINS

Human cationic trypsin $(8.8 \mathrm{mg})$ inactivated by DFP was conjugated to $1 \mathrm{~g}$ of Sepharose $4 \mathrm{~B}$, and $15 \mathrm{mg}$ similarly inactivated human anionic trypsin was coupled to $1.5 \mathrm{~g}$ of Sepharose $4 \mathrm{~B}$, according to the manufacturer's instructions. Two separate columns, $0.9 \times$ $7 \mathrm{~cm}$ and $0.9 \times 11 \mathrm{~cm}$, were equilibrated in a glycine buffer, $0 \cdot 1 \mathrm{M} / 1$, containing sodium chloride $0 \cdot 15 \mathrm{M} / \mathrm{l}$, ethylene diamino tetra-acetate $0.005 \mathrm{M} / 1$, and sodium nitrate $0.02 \%$ at $\mathrm{pH} 6.8$. Rabbit antiserum against human anionic trypsin $(25 \mathrm{ml})$ was applied to the sepharose cationic DFP-trypsin column. The column was then washed with the same glycine buffer. The fractions containing protein were pooled and applied to the sepharose anionic DFP-trypsin column. The column was washed with the same glycine buffer until absorbance at $280 \mathrm{~nm}$ was below $0 \cdot 1$. Then the specific antibodies against human anionic trypsin were eluted with a glycine buffer, $0 \cdot 1 \mathrm{M} / 1$, containing sodium chloride $0 \cdot 15 \mathrm{M} / 1$, sodium thiocyanate $3 \cdot 5 \mathrm{M} / \mathrm{l}$, ethylene diamino tetra-acetate $0.005 \mathrm{M} / 1$, and sodium nitrate $0.02 \%$ at $\mathrm{pH} 7 \cdot 3$. The absorption at $280 \mathrm{~nm}$ of the effluent was measured and the fractions containing antibody were pooled and dialysed against water.

The antiserum against human cationic trypsin was processed in the same way; first being filtered through the sepharose-anionic DFP-trypsin column, with the effluent from this column then being applied to the Sepharose-cationic-DFP-trypsin column. After washing with the starting buffer to an absorption at $280 \mathrm{~nm}$ of less than $0 \cdot 1$ the specific antibodies against human cationic trypsin were eluted with the buffer described above. The fractions containing antibodies

Table Pancreatic endoproteases and PSTI immunoreactivity in Paneth cells in investigated specimens with positive immunohistochemical staining

\begin{tabular}{|c|c|c|c|c|c|}
\hline & Anionic trypsin & Cationic trypsin & PSTI & Chymotrypsin & Elastase \\
\hline \multicolumn{6}{|l|}{ Normal mucosa: } \\
\hline Duodenum & $4 / 4$ & $4 / 4$ & $4 / 4$ & $0 / 4$ & $0 / 4$ \\
\hline Jejunum & $4 / 4$ & $4 / 4$ & $4 / 4$ & $0 / 4$ & $0 / 4$ \\
\hline Ileum & $4 / 4$ & $4 / 4$ & $4 / 4$ & $0 / 4$ & $0 / 4$ \\
\hline \multicolumn{6}{|l|}{ Metaplastic mucosa: } \\
\hline Stomach & $4 / 4$ & $4 / 4$ & $4 / 4$ & $0 / 4$ & $0 / 4$ \\
\hline Colon (ulcerative colitis) & $5 / 6$ & $5 / 6$ & $5 / 6$ & $0 / 6$ & $0 / 6$ \\
\hline Adenoma (Paneth cell metaplasia) & $1 / 1$ & $1 / 1$ & $1 / 1$ & $0 / 1$ & $0 / 1$ \\
\hline
\end{tabular}




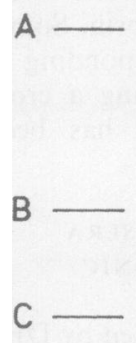

Fig. 1 Precipitation patterns obtained by immunoelectrophoresis of pancreatic juice with $(A)$ rabbit anticationic trypsin serum. (B) rabbit antianionic trypsin serum, and (C) rabbit anti-PSTI serum. Arrow denotes application points.

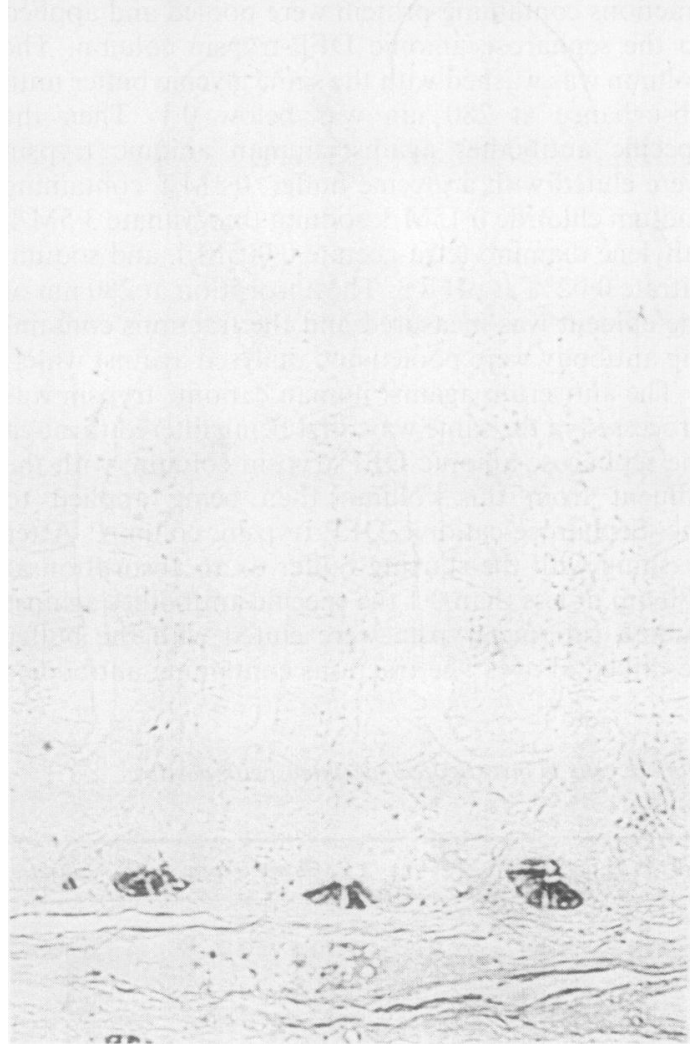

Fig. 2 Normal jejunal mucosa. Lysozyme shown within Paneth cells by immunohistochemical staining. $\times 160$.

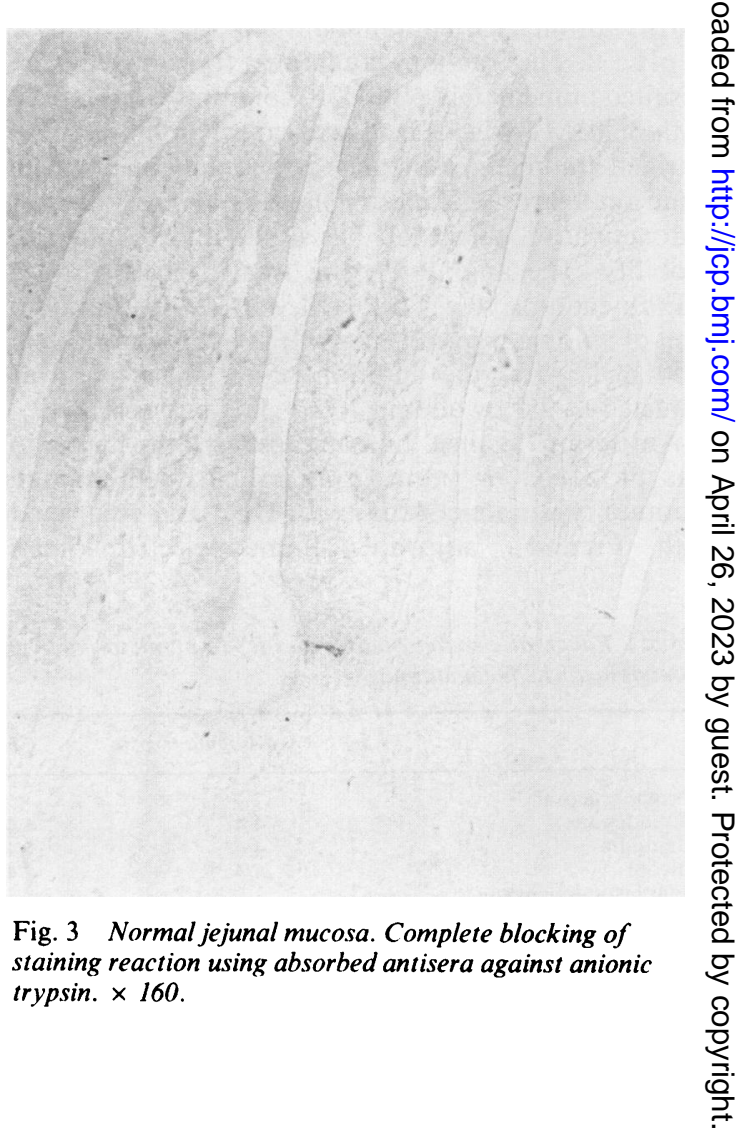




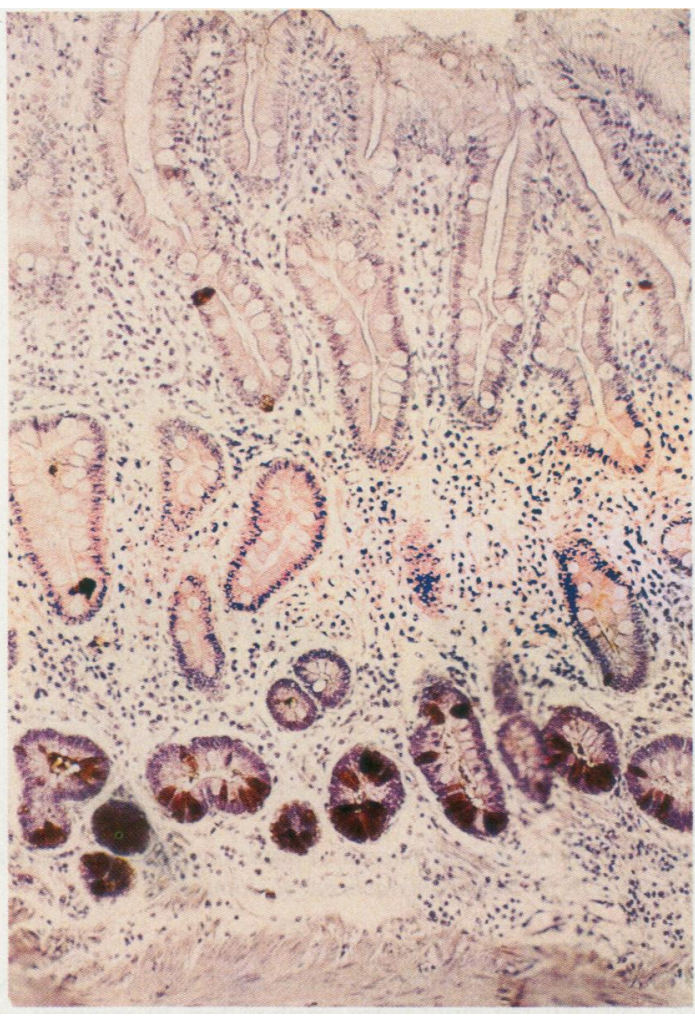

Fig. 4

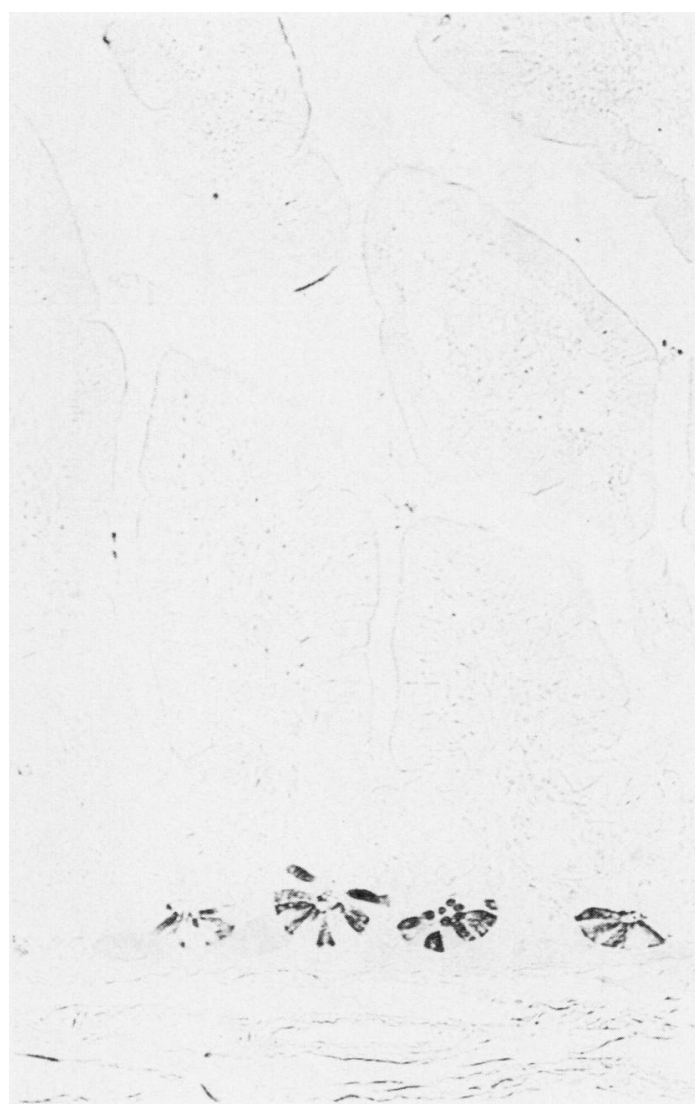

Fig. 6

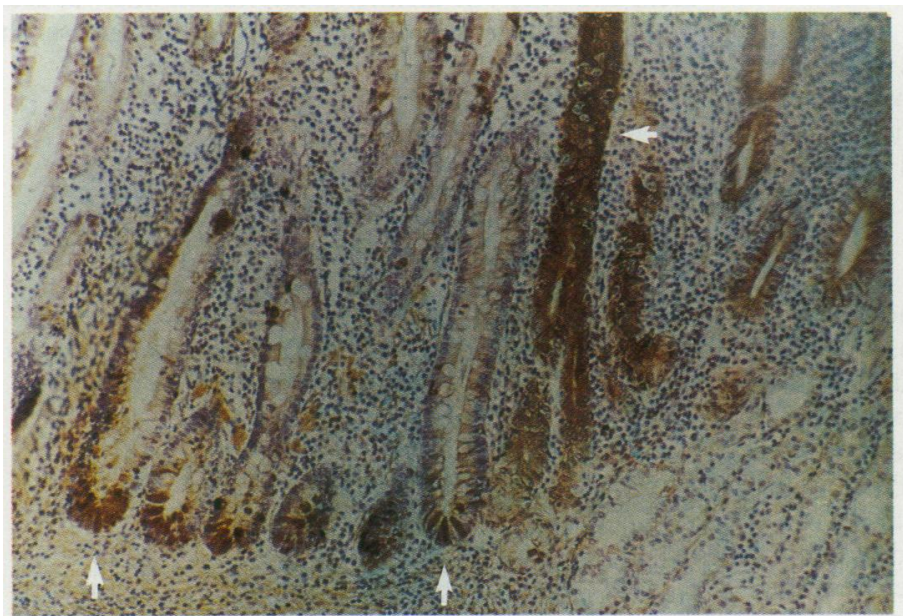

Fig. 4 Gastric mucosa with focal intestinal metaplasia. Anionic trypsin shown within Paneth cells by immunohistochemical staining. (Haematoxylin and eosin.) $\times 160$.

Fig. 5 Gastric mucosa of fundus type with chronic gastritis and severe intestinal metaplasia. PSTI shown within Paneth cells (arrow heads) as well as in normal glands (arrow) by immunohistochemical staining. (Haematoxylin and eosin.) $\times 160$.

Fig. 6 Normal jejunal mucosa. Anionic trypsin shown within Paneth cells by immunohistochemical staining. $\times 160$

Fig. 5 


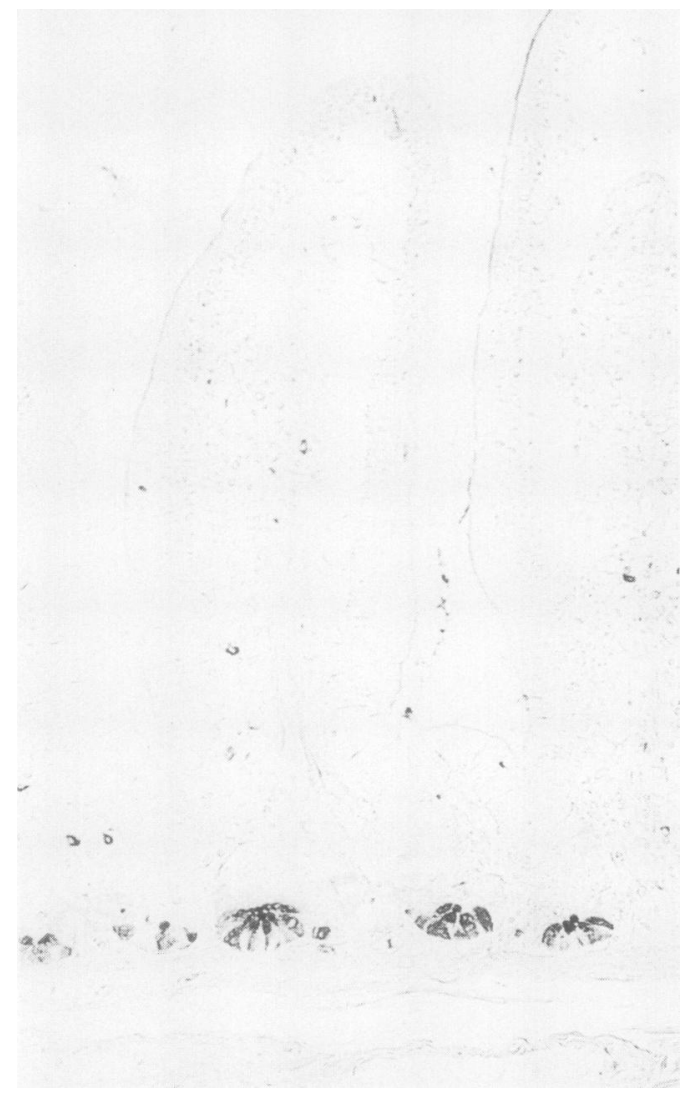

Fig. 7 Normal jejunal mucosa. Cationic trypsin shown within Paneth cells by immunohistochemical staining. $\times 160$.

were pooled and dialysed against water.

The immunoadsorbed specific rabbit antibodies against human anionic and cationic trypsins were checked by immunoelectrophoresis against human pancreatic juice. The antibodies were used in dilutions made from a stock solution of $2 \mathrm{mg} / \mathrm{ml}$.

\section{IMMUNOHISTOCHEMICAL METHODS}

The tissue samples were stained with haematoxylin and eosin and analysed with light microscopy. The peroxidase-antiperoxidase (PAP) method described by Sternberger et al ${ }^{10}$ with the slight modification already mentioned, ${ }^{11}$ was used for localisation of the different pancreatic endoproteases, PSTI, and lysozyme. The antisera were used in serial dilutions $1 / 100$ to $1 / 2000$. Controls were performed with each new staining series using the antisera after immunosorbent absorption with their appropriate antigens and non-immune rabbit serum. Swine antirabbit IgG

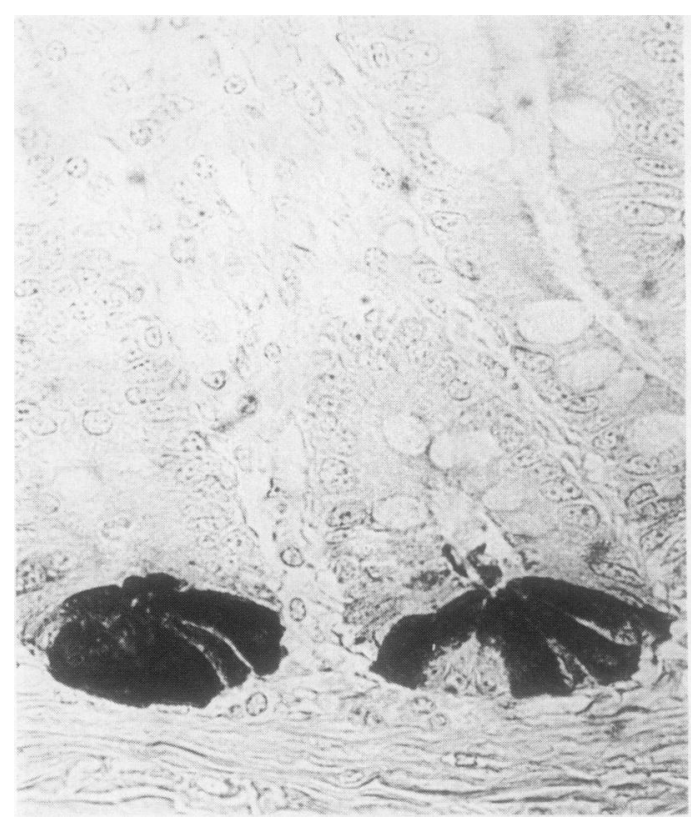

Fig. 8 Normal jejunal mucosa. Anionic trypsin shown within Paneth cells by immunohistochemical staining. $\times 640$.

and peroxidase complexes were used in the dilutions of $1 / 50$. All reagents were applied for 30 minutes at $\stackrel{\unrhd}{\unrhd}$ room temperature in a humidified chamber.

\section{Results}

After immunoabsorption of the anionic and cationie trypsin antisera no cross reactivity between them was seen, and only one distinct precipitation line was seen? on immunoelectrophoresis for each antiserum (Fig. 1).

Fig. 9 Normal duodenal mucosa. PSTI shown in Paneth cells as well as goblet cells by immunohistochemical staining (Haematoxylin and eosin.) $\times 1600$.

Fig. 10 Colonic mucosa in a case of ulcerative colitis with intestinal metaplasia containing Paneth cells. Anionic trypsin shown within Paneth cells by immunohistochemical staining. $\times 160$.

Fig. 11 Colonic adenoma containing Paneth cells. Anionic trypsin shown within Paneth cells by immunohistochemical staining. (Haematoxylin and eosin.) $\times 160$.

Fig. 12 Colonic adenoma containing Paneth cells. PSTI shown within Paneth cells by immunohistochemical staining. (Haematoxylin and eosin.) $\times 160$. 


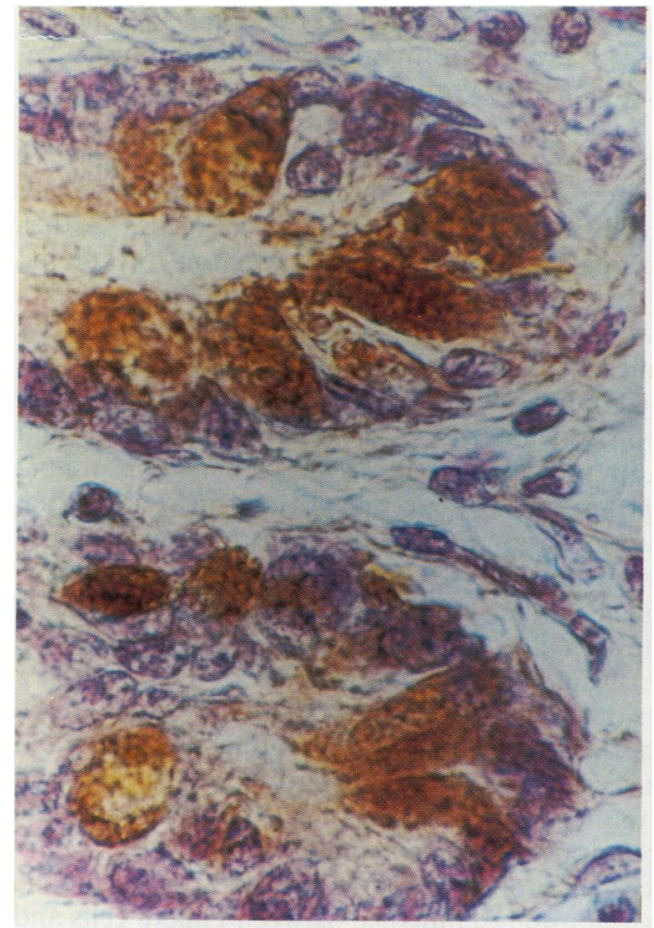

Fig. 9

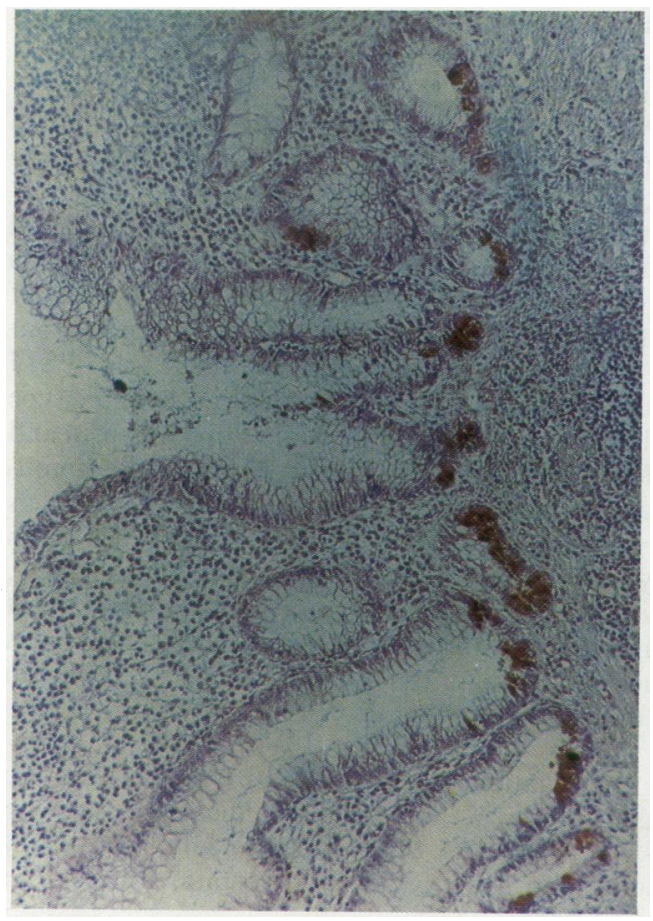

Fig. 10

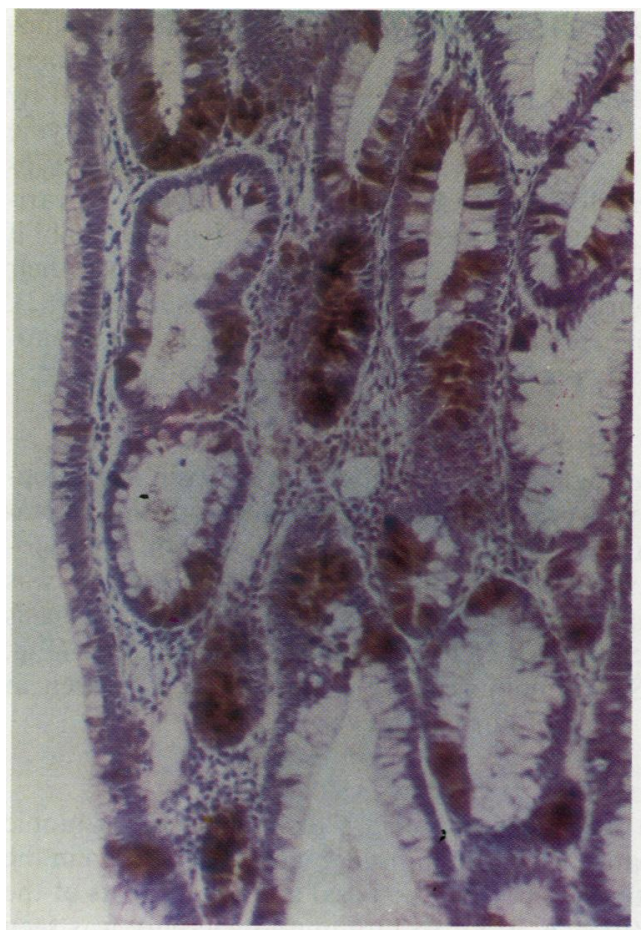

Fig. 11

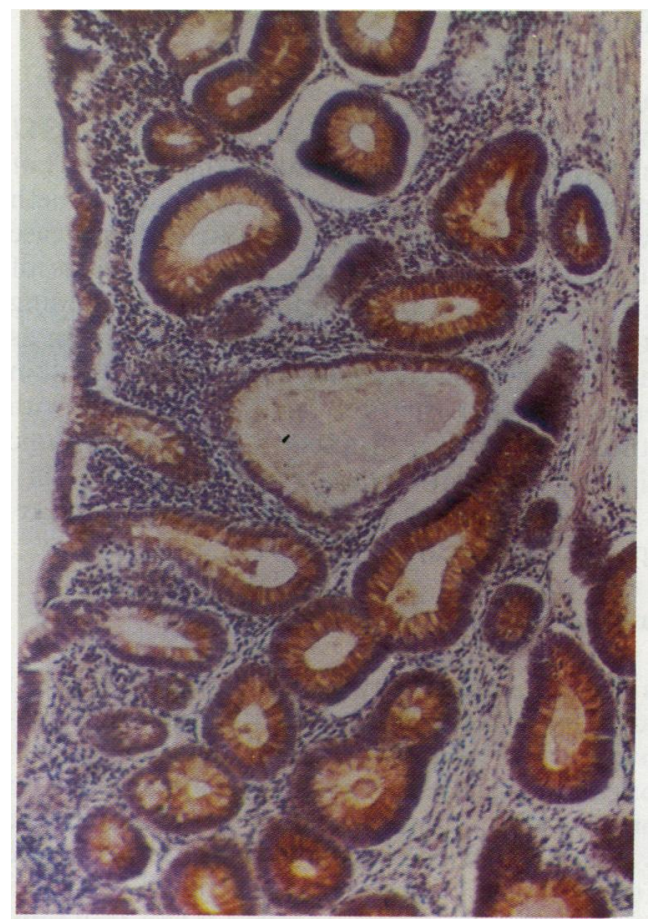

Fig. 12 
The Table shows the results of the immunohistochemical staining. The Paneth cells were identified on the basis of histological criteria and by their immunohistochemical staining for lysozyme (Fig. 2). A positive brown staining for the two trypsins and for PSTI was evident in Paneth cells of various locations. Control sections with normal rabbit sera or antisera previously absorbed against their appropriate antigens yielded negative results. (Fig. 3). No pancreatic chymotrypsin or elastase immunoreactivity could be shown in any control specimen.

\section{STOMACH}

In normal gastric mucosa no trypsin immunoreactivity was identified. In areas of intestinal metaplasia with Paneth cells a distinct trypsin immunoreactivity of both anionic and cationic types was identified in the Paneth cells (Fig. 4). The Paneth cells also contained PSTI immunoreactive material (Fig. 5). PSTI immunoreactive material was also seen in some areas of normal mucosa.

\section{DUODENUM, JEJUNUM, AND ILEUM}

In all specimens analysed a distinct positive anionic and cationic trypsin immunoreactivity was seen in the Paneth cells, both in the basal and apical parts of the cells (Figs. 6, 7, 8). PSTI immunoreactivity was seen in some Paneth cells and also in goblet cells in the basal parts of the glandular crypts of Lieberkühn (Fig. 9).

\section{COLON}

In the normal colonic mucosa a positive PSTI immunoreactivity was seen mainly in the basal part of the crypts. In the normal colonic mucosa no Paneth cells were identified, and no pancreatic endoprotease immunoreactivity was seen. In metaplastic areas of the mucosa in cases with ulcerative colitis, containing Paneth cells, positive anionic and cationic trypsin as well as PSTI immunoreactivity were identified within the cells (Fig. 10). In one case of adenoma with Paneth cell metaplasia distinct anionic and cationic trypsin immunoreactivity were identified (Fig. 11). PSTI immunoreactive material was also stored in various parts of the adenoma (Fig. 12).

\section{Discussion}

In a recent study using immunohistochemical methods, ${ }^{5}$ we reported on trypsin like immunoreactivity in the human Paneth cells in normal mucosa and in metaplastic areas of gastric mucosa. In the present study it was necessary to eliminate the cross reacting antibodies from each antiserum as the two trypsins show some cross reactivity. This was accomplished using an immunoabsorption technique with the two isolated antigens bound in a solid phase. Applying the respective specific antibodies, we showed that the trypsin like immunoreactivity in the Paneth cells was of anionic and cationic types. The $\bar{s}$ positive brown staining was completely abolished in the controls using the specific antisera previously $\frac{\bar{O}}{\sigma}$ absorbed with their appropriate antigens, further $\overline{\bar{c}}$ confirming the specificity of the reaction for anionic $\Phi$ trypsin and cationic trypsin.

The Paneth cells of all tissues studied were easily identified according to their histological criteria and $\vec{\circ}$ by their immunochemical staining for lysozyme. In $\vec{\overrightarrow{ }}$ addition to Paneth cells of metaplastic and normal $\sigma_{\infty}$ types, immunoreactive PSTI was seen in areas of nor-응 mal gastric and colonic mucosa and in some goblet $\frac{}{\omega}$ cells in the basal parts of the crypts of Lieberkühn in the small intestine. No immunoreactive trypsin was. identified in the goblet cells. Thus immunoreactive trypsin was always accompanied by immunoreactive PSTI, fitting the general concepts of Laskowsky: ${ }^{12} \supset$ tissues that contain a protease also always contain the $\vec{C}$ appropriate inhibitor. Further direct isolation and characterisation of these immunoreactivities will $\vec{\oplus}$ probably clarify the presence of PSTI in some cellso without apparent trypsin content.

A common observation in published reports is the ultrastructural resemblance between Paneth cells and the acinar pancreatic cells. ${ }^{4}$ Several findings also point to a functional resemblance. Paneth cells are of: secretory type. Pilocarpine has been shown toळ increase the secretion from these cells. ${ }^{13}$ Trasylol, a $\overrightarrow{0}$ potent trypsin inhibitor, increases the granule size in 3 the Paneth cells. ${ }^{14}$ Studies in hamsters have shown that pancreatic duct ligation was followed by degen-o. eration of exocrine pancreas and caused a hyper trophy of Paneth and goblet cells. ${ }^{15}$ The duodenal? mucosa in patients suffering from chronic pancreatitis showed an appreciable increase in the number of Paneth cells. ${ }^{16}$ These data, as well as our proof that both trypsin immunoreactive material and PSTI immunoreactive material are present in the same type of cells, argue the case for a production of trypsin and PSTI in the Paneth cells. The findings of both immunoreactive anionic and cationic trypsin, as well as their appropriate inhibitor PSTI in Paneth cells, from a physiological and pathophysiological point of view show that the Paneth cells are probably an important ${ }^{\omega}$ extrapancreatic source of these enzymes and give aर further indication of the resemblance between Panetke cells and acinar pancreatic cells.

This investigation was supported by grants from the Swedish Medical Research Council (project noके B86-17X-0390-14A), the Medical Faculty, University $\frac{\stackrel{P}{\mathbb{P}}}{2}$ of Lund, and Malmö General Hospital Foundation against Cancer. 


\section{References}

${ }^{1}$ Schwalbe G. Beiträge zur Kenntnis der Drüsen in der Darmwandungen, in's Besondere der Brunner'schen Drüsen. Archiv für Mikroskepische Anatomie 1872;8:92-140.

${ }^{2}$ Paneth J. Über die secernierenden Zellen des Dünndarm-Epithels. Archiv für Mikroskepische Anatomie 1888;31:113-91.

${ }^{3}$ Lewin K. The Paneth cell in disease. Gut 1969:10:804-11.

${ }^{4}$ Sandow M, Whitehead R. The Paneth cell. Gut 1979;20:420-31.

${ }^{5}$ Bohe M, Borgström A, Lindström C, Ohlsson K. Trypsin-like immunoreactivity in human Paneth cells. Digestion 1984:30: $271-5$.

${ }^{6}$ Ohlsson K, Skude G. Demonstration and semiquantitative determination of complexes between various proteases and human $\alpha_{2}$-macroglobulin. Clin Chim Acta 1976;66:1-7.

${ }^{7}$ Eddeland A, Ohlsson K. Purification and immunochemical quantitation of human pancreatic secretory trypsin inhibitor. Scand $J$ Clin Lab Invest 1978;38:261-7.

${ }^{8}$ Bohe M, Borgström A, Genell S, Ohlsson K. Determination of immunoreactive trypsin, pancreatic elastase and chymotrypsin in extracts of human faeces and ileostomy drainage. Digestion 1983:27:8-15.

${ }^{9}$ Feinstein G, Hofstein R, Koifmann J, Sokolovsky M. Human pancreatic proteolytic enzymes and protein inhibitors. Isolation and molecular properties. Eur J Biochem 1974:43:569-81.

${ }^{10}$ Sternberger LA, Hardy PH, Cuculis JJ, Meyer HG. The unlabeled antibody enzyme method of immunohistochemistry. Prepara- antibody enzyme method of immunohistochemistry. Preparations and properties of soluble antigen-antibody complex (horseradish peroxidase-antihorseradish peroxidase) and its use in identification of spirochetes. J Histochem Cytochem 1970;18: $315-33$.

${ }^{11}$ Fryksmark U, Ohlsson K, Polling $\AA$, Tegner H. Distribution of antileukoprotease in upper respiratory mucosa. Ann Otol Rhinol Laryingol 1982;91:268-78.

12 Laskowsky JRM. Resumé in proteinase inhibitors. Fritz, Tschesche H, Greene L, Truscheit E, eds. Springer-Verlag, 1974: 679-84.

${ }^{13}$ Trier JS, Lorenzsonn V, Groehler K. Pattern of secretion of Paneth cells of the small intestine of mice. Gastroenterology 1967:53:240-9.

${ }^{14}$ Ahonen A, Penttilä A. Effect of Trasylol on Paneth cells of the mouse. Experientia 1975:31:577-8.

${ }^{15}$ Balas D, Senegas-Balas F, Bertrand C, Frexinos J, Ribet A. Effects of pancreatic duct ligation of the hamster intestinal mucosa. Digestion 1980;20:157-67.

${ }^{16}$ Senegas-Balas F, Bastie MJ, Balas D, et al. Histological variations of the duodenal mucosa in chronic human pancreatitis. Dig Dis Sci 1982;27:917-22.

Requests for reprints to: Dr Måns Bohe, Department of Surgery, Malmö General Hospital, S-21401 Malmö, Sweden. 